\title{
ANALISIS PERBANDINGAN MATERIAL AGREGAT TERHADAP KARAKTERISTIK CAMPURAN ASPHALT CONCRETE WEARING COURSE (AC-WC)
}

\author{
(Analysis of Aggregate Materials Comparison to Mixture Characteristic of Asphalt Concrete Wearing \\ Course (AC-WC))
}

\author{
Naela Aesara ${ }^{1}$, Imam Hagni Puspito ${ }^{1}$, Nuryani Tinumbia ${ }^{1}$ \\ ${ }^{1}$ Program Studi Teknik Sipil Universitas Pancasila \\ E-mail: naelaesara12@gmail.com
}

\begin{abstract}
ABSTRAK
Setiap agregat memiliki karakteristik yang berbeda-beda dari satu wilayah dengan wilayah yang lain, bahkan dari satu lokasi dengan lokasi yang lain dalam wilayah yang sama. Kebanyakan konstruksi jalan di Wilayah Jabodetabek menggunakan material agregat yang bersumber dari tiga quarry di Jawa Barat yaitu Gunung Bitung, Gunung Rumpin, dan Gunung Sudamanik. Penelitian ini bertujuan untuk menganalisis perbandingan karakteristik campuran aspal material agregat dari tiga quarry tersebut melalui nilai karakteristik Marshall pada campuran beton aspal dengan menggunakan Spesifikasi Bina Marga Revisi III (2010). Metode eksperimental digunakan untuk mengetahui material agregat mana yang baik untuk konstruksi beton aspal dengan proporsi campuran agregat yaitu Agregat kasar 38\%, Agregat Sedang 17\% dan Agregat Halus 45\% terhadap total campuran aspal yang telah ditentukan oleh Bina Marga (2010). Pengujian pada campuran aspal dengan material dari tiga quarry tersebut didapat kadar aspal optimum (KAO) masing-masing 6,65\%, $5,85 \%$, dan $6,65 \%$. Hasil pengujian Marshall didapat nilai parameter karakteristik campuran untuk campuran aspal dengan material dari Gunung Bitung berupa VIM (4,40\%), VMA (17,30\%), VFB (74,30\%), Stabilitas (1180 Kg), Flow $(3,63$ $\mathrm{mm}), \mathrm{MQ}(218 \mathrm{~kg} / \mathrm{mm})$, untuk campuran aspal dengan material dari Gunung Rumpin berupa VIM (4,14\%), VMA $(16,53 \%)$, VFB $(74,80 \%)$, Stabilitas $(1120 \mathrm{Kg})$, Flow $(3,62 \mathrm{~mm}), \mathrm{MQ}(318 \mathrm{~kg} / \mathrm{mm})$ dan untuk campuran aspal dengan material dari Gunung Sudamanik berupa VIM (3,84\%), VMA $(17,23 \%)$, VFB $(77,20 \%)$, Stabilitas $(1253 \mathrm{Kg})$, Flow $(3,22$ $\mathrm{mm}), \mathrm{MQ}(389 \mathrm{~kg} / \mathrm{mm})$. Hasil karakteristik Marshall pada KAO untuk campuran aspal dengan material dari Gunung Bitung, Gunung Rumpin, dan Gunung Sudamanik telah memenuhi spesifikasi, namun material dari quarry Gunung Sudamanik memiliki karakteristik paling baik diantara ketiganya.
\end{abstract}

Kata Kunci : Perbandingan Material Agregat, Karakteristik Marshall, KAO, Campuran Aspal Beton, Karakteristik Campuran Aspal

\section{ABSTRACT}

Every material has different characteristics from one region to another, even from one location to another in the same area. The road constructions in Jabodetabek area use aggregate material sourced from three quarries in West Java, namely Gunung Bitung, Gunung Rumpin, and Gunung Sudamanik. This study aims to analyze the characteristic comparison of asphalt aggregate mixtures from the three quarries through Marshall characteristic values on asphalt concrete mixtures using the Bina Marga Specification III Revision (2010). The experimental method is used to determine which aggregate material is good for asphalt concrete construction with aggregate mixture proportions of coarse aggregate $38 \%$, medium aggregate $17 \%$ and fine aggregate $45 \%$ of the total asphalt mixture determined by Bina Marga (2010). Based on testing, the Optimum Asphalt Content (OAC) obtained were 6.65\%, 5.85\%, and 6.65\%. Marshall test results obtained VIM (4.40\%), VMA (17.30\%), VFB (74.30\%), Stability $(1180 \mathrm{Kg})$, Flow (3.63 mm), MQ (218 kg / mm) for asphalt mixture with Gunung Bitung materials; VIM (4.14\%), VMA (16.53\%), VFB (74.80\%), Stability (1120 Kg), Flow (3.62 mm), MQ (318 kg / mm) for asphalt mixture with Gunung Rumpin materials; and VIM (3.84\%), VMA (17.23\%), VFB (77.20\%), Stability $(1253 \mathrm{Kg})$, Flow $(3.22 \mathrm{~mm}), M Q(389 \mathrm{~kg} / \mathrm{mm})$ for asphalt mixture Gunung Sudamanik materials. The results of Marshall characteristics on KAO for asphalt mixtures with each materials have met the specifications, but the Gunung Sudamanik materials has the best characteristics among the three.

Keywords : Comparison of Aggregate Materials, Marshall Characteristics, Optimum Asphalt Content, Concrete Asphalt Mixture, Characteristic of Asphalt Mix 


\section{PENDAHULUAN}

Pertumbuhan volume lalu lintas semakin meningkat dengan pesat akibat pertumbuhan dan perkembangan kota serta laju pertumbuhan penduduk yang mempengaruhi mobilisasi penumpang maupun barang sehingga memicu kerusakan pada jalan dimana beban lebih besar daripada kemampuan jalan untuk memikul beban. Kondisi tersebut harus didukung oleh konstruksi jalan yang berkualitas untuk memberikan kenyamanan dalam berkendara. Kerusakan jalan telah menjadi permasalahan yang sering dihadapi. Hal tersebut menyebabkan umur jalan lebih pendek dari perencanaan. Perkerasan lentur merupakan perkerasan yang umum digunakan pada struktur perkerasan jalan. Perkerasan ini umumnya ekonomis, mempunyai sifat yang lentur dan permukaan yang lebih rata sehingga perkerasan lentur ini mempunya tingkat kenyamanan yang lebih tinggi dari perkerasan jenis lainnya.

Untuk penggunaan agregat dari alam sudah banyak quarry yang beroperasi di daerah-daerah Indonesia terlebih khusus di daerah Jawa Barat. Setiap agregat memiliki karakteristik yang berbeda-beda dari satu wilayah dengan wilayah yang lain, bahkan dari satu lokasi dengan lokasi yang lain dalam wilayah yang sama. Oleh karena itu penelitian ini akan meninjau material yang ada di beberapa sumber di wilayah Jawa Barat yang digunakan untuk pembangunan infrastruktur di Indonesia khususnya di Jabodetabek. Pada saat ini pembangunan infrastruktur di Indonesia semakin meningkat, maka dari itu diperlukan materialmaterial yang berkualitas tinggi untuk mencapai mutu yang diinginkan. Daerah Jawa Barat terdapat banyak quarry yang menghasilkan material yang berkualitas, maka dari itu material agregat yang digunakan dalam penelitian ini yaitu material agregat dari quarry Gunung Bitung, Gunung Rumpin, dan Gunung Sudamanik dibandingkan sebagai acuan pembanding yang sudah dikenal memiliki karakteristik yang baik.

Maksud dari penelitian ini adalah untuk mengetahui perbandingan material agregat kasar, agregat sedang, dan agregat halus dengan melakukan analisis campuran AC-WC sehingga dapat diketahui material lokl yang lebih unggul khususnya di Wilayah Jawa Barat.

Tujuan dilakukannya penelitian yaitu mengetahui material yang memiliki kinerja paling baik dibandingkan dengan sumber material lainnya..

Penggunaan Laston AC-WC (Asphalt Concrete Wearing Course) yaitu untuk lapis permukaan paling atas dalam perkerasan dan mempunyai tekstur yang paling halus dibandingkan dengan jenis laston lainnya. Pada campuran laston yang bergradasi menerus tersebut mempunyai sedikit rongga dalam struktur agregatnya dibandingkan dengan campuran bergradasi senjang. Hal tersebut menyebabkan campuran AC-WC lebih peka terhadap variasi dalam proporsi campuran. Berikut merupakan persyaratan laston dalam lapis perkerasan yang dapat dilihat pada Tabel 1. yang dikeluarkan oleh Kementrian Pekerjaan Umum Direktorat Jenderal Bina Marga tahun 2010 revisi III.

Tabel 1. Ketentuan Sifat-Sifat Campuran Laston (AC)

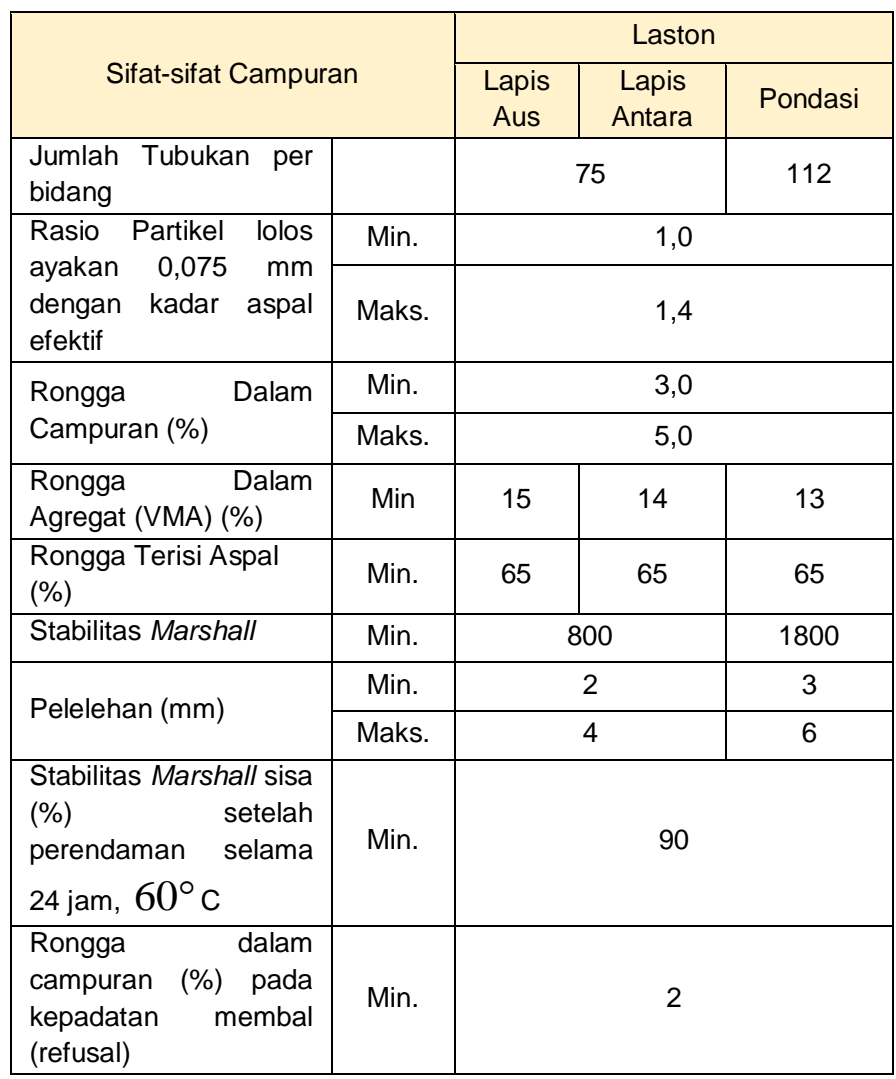

(Sumber : Spesifikasi Umum Bina Marga, 2010)

\section{Karakteristik Campuran Aspal}

Dalam merencanakan campuran aspal yang akan digunakan untuk perkerasan jalan terdapat karakteristik yang harus dimiliki oleh campuran aspal tersebut. Berikut ini adalah karakteristik campuran aspal yang harus dimiliki, menurut Sukirman (2003) :

\section{Stabilitas}

Stabilitas adalah kemampuan lapisan perkerasan menerima beban lalu lintas tanpa terjadi perubahan bentuk tetap seperti gelombang, alur dan bleeding. Kebutuhan akan stabilitas setingkat dengan jumlah lalu lintas dan beban kendaraan yang akan memakai jalan tersebut. Jalan dengan volume lalu lintas tingg dan sebagian besar merupakan kendaraa berat menuntut stabilitas yang lebih besar dibandingkan dengan jalan dengan volume lalu lintas yang hanya terdiri dari kendaraan penumpang saja. Kestabilan yang terlalu tinggi menyebabkan lapisan itu menjadi kaku dan cepat mengalami retak, disamping itu karena volume antar agregat kurang, hal ini menghasilkan film aspal tipis dan mengakibatkan ikatan aspal mudah lepas sehingga durabilitasnya rendah.

\section{Durabilitas}

Durabilitas diperlukan pada lapisan permukaan sehingga lapisan dapat mampu menahan 
keausan akibat pengaruh cuaca, air dan perubahan suhu ataupun keausan akibat gesekan kendaraan. Faktor yang mempengaruhi durabilitas adalah sebagai berikut :

a. Film aspal atau selimut aspal, film aspal yang tebal dapat menghasilkan lapis aspal beton yang berdurabilitas tinggi, tetapi kemungkinan terjadinya bleeding menjadi tinggi.

b. VIM kecil sehingga lapis kedap air dan udara tidak masuk kedalam campuran yang menyebabkan terjadinya oksidasi dan aspal menjadi rapuh/getas.

c. VMA besar, sehingga film aspal dapat dibuat tebal. Jika VMA dan VIM kecil serta kadar aspal tinggi kemungkinan terjadinya bleeding besar. Untuk mencapai VMA yang besar dipergunakan agregat bergradasi senjang.

\section{Fleksibilitas (Kelenturan)}

Fleksibilitas pada lapisan perkerasan adalah kemampuan lapisan untuk dapat mengikuti deformasi yang terjadi akibat beban lalu lintas berulang tanpa timbulnya retak dan perubahan volume. Fleksibilitas dapat diperoleh dengan :

a. Penggunaan agregat bergradasi senjang sehingga diperoleh VMA yang besar.

b. Penggunaan aspal lunak (aspal dengan penetrasi yang tinggi).

c. Penggunaan aspal yang cukup banyak sehingga diperoleh VIM yang kecil.

\section{Tahanan Geser (Skid Resistance)}

Tahanan geser adalah kekesatan yang diberikan oleh perkerasan sehingga kendaraan tidak mengalami slip baik di waktu hujan atau basah maupun di waktu kering. Kekesatan dinyatakan dengan koefisien gesek antar permukaan jalan dan ban kendaraan. Tahanan geser tinggi jika :

a. Penggunaan kadar aspal yang tepat sehingga tak terjadi bleeding.

b. Penggunaan agregat dengan permukaan kasar.

c. Penggunaan agregat berbentuk kubus.

d. Penggunaan agregat kasar yang cukup.

5. Kemudahan Pekerjaan (Workability)

Kemudahan pekejaan adalah mudahnya suatu campuran untuk dihampar dan dipadatkan sehingga diperoleh hasil yang memenuhi kepadatan yang diharapkan. Faktor yang mempengaruhi kemudahan dalam pelaksanaan adalah :

a. Gradasi agregat, agregat bergradasi baik lebih mudah dilaksanakan dari pada agregat bergradasi lain.

b. Temperatur campuran, ynag ikut mempengaruhi kekerasan bahan pengikat yang bersifat termoplastis.

c. Kandungan bahan pengisi (filler) yang tinggi menyebabkan pelaksanaan lebih sukar.

6. Ketahanan Kelelahan (Fatique Resistance)Ketahanan kelelahan adalah ketahanan dari lapis aspal beton dalam menerima beban berulang tanpa terjadinya kelelahan yang berupa alur (rutting) dan retak. Faktor yang mempengaruhi ketahanan terhadap kelelahan adalah :

a. VIM yang tinggi dan kadar aspal yang rendah akan mengakibatkan kelelahan lebih cepat.

b. VMA yang tinggi dan kadar aspal yang tinggi dapat mengakibatkan lapis perkerasan menjadi fleksibel.

\section{METODE}

Metode penelitian yang digunakan dalam penelitian ini adalah metode eksperimental dengan melakukan seluruh kegiatan percobaan dilakukan di dalam Laboratorium AMP. PT. Prayoga Pertambangan dan Energi yang bertempat di Desa Babakan Madang, Sentul-Bogor Jawa Barat, untuk lebih lanjut mengenai langkah-langkah pengujian dalam melakukan penelitian ini dapat dilihat pada Gambar 1. Flow Chart Penelitian :

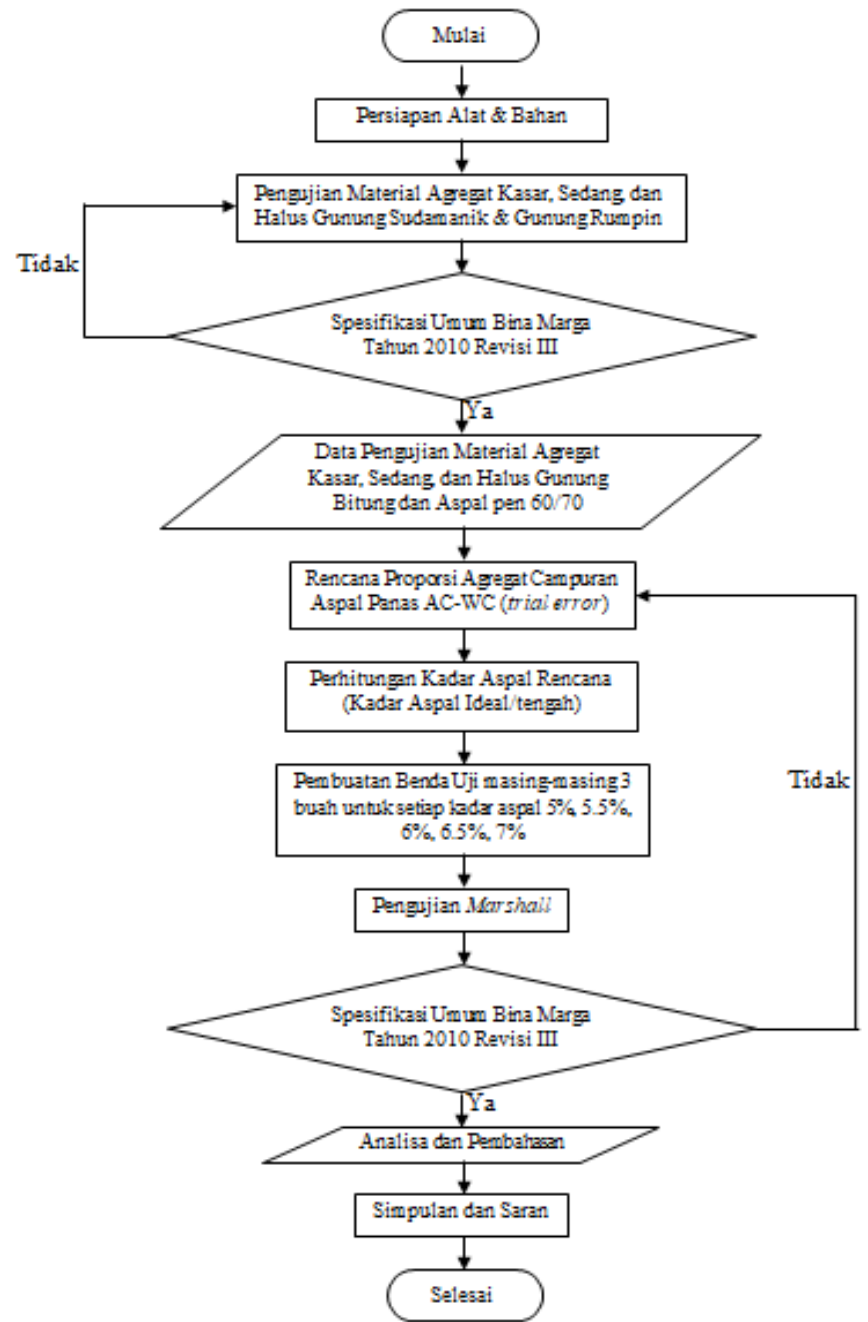

Gambar 1. Flow Chart Penelitian

\section{Peralatan yang digunakan :}

Peralatan yang digunakan dalam penelitian ini adalah sebagai berikut : 


\section{Satu Set Saringan (Sieve)}

Penggunaan alat saringan digunakan untuk memisahkan agregat berdasarkan gradasi/ukuran agregat.

\section{Alat Uji Pemeriksaan Agregat}

Dalam penelitian ini dilakukan pemeriksaan agregat peralatan yang digunakan untuk pengujian agregat antara lain alat pengering yaitu oven, timbangan berat, alat uji berat jenis (piknometer, timbangan dan pemanas).

3. Alat Uji Karakteristik Campuran Agregat Dan Aspal

Alat uji yang digunakan adalah seperangkat alat untuk metode marshall, meliputi :

a. Alat tekan marshall yang terdiri dari kepala penekan berbentuk lengkung, cincin penguji berkapasitas 22,2 KN (5000 lbs) yang dilengkapi dengan arloji pengukur flowmeter.

b. Alat cetak benda uji berbentuk silinder diameter 4 inchi $(10,16 \mathrm{~cm})$ dan tinggi 3 inchi $(7,5 \mathrm{~cm})$.

c. Alat tumbuk yang digunakan untuk pemadatan campuran sebanyak 75 kali tumbukan tiap sisi (atas dan bawah).

d. Ejektor untuk mengeluarkan benda uji setelah proses pemadatan.

e. Bak perendam (water bath) yang dilengkapi pengatur suhu.

f. Alat-alat penunjang yang meliputi penggorengan pencampur, kompor pemanas, termometer, sendok pengaduk, sarung tangan anti panas, kain lap, timbangan, ember untuk merendam benda uji, jangka sorong, pan, dan tipe- $x$ yang digunakan untuk menandai benda uji.

\section{Bahan-bahan yang digunakan :}

Bahan-bahan yang digunakan dalam penelitian ini adalah:

\section{Aspal}

Aspal yang digunakan dalam penelitian ini adalah aspal Pertamina dengan nilai penetrasi 60/70 yang telah disediakan oleh PT. Prayoga pertambangan dan energi.

2. Agregat Kasar

Agregat kasar yang digunakan dalam penelitian ini adalah agregat yang berasal dari quarry Gunung Bitung, Bogor, Jawa Barat. Agregat kasar ini sudah disediakan oleh PT. Prayoga Pertambangan dan Energi.

\section{Agregat Sedang}

Agregat sedang yang digunakan dalam penelitian ini adalah agregat yang berasal dari quarry Gunung Bitung, Bogor, Jawa Barat. Agregat kasar ini sudah disediakan oleh PT. Prayoga Pertambangan dan Energi.

\section{Agregat Halus}

Agregat halus yang digunakan dalam penelitian ini adalah agregat yang berasal dari quarry Gunung Bitung, Bogor, Jawa Barat. Agregat halus ini sudah disediakan oleh PT. Prayoga

Pertambangan

dan

Energi.

\section{Parameter dan Formula Perhitungan}

Parameter dan formula untuk menganalisa campuran aspal panas adalah sebagai berikut :

\section{Kadar Aspal Rencana}

Perkiraan kadar aspal optimum dapat direncanakan setelah dilakukan pemilihan dan penggabungan pada tiga fraksi agregat. Sedangkan perhitungannya adalah sebagai berikut :

$P_{b}=0,035(\% C A)+0,045(\% F A)+0,18(\% F F)+K$

Keterangan :

$\mathrm{P}_{\mathrm{b}} \quad=$ Perkiraan kadar aspal optimum

$\mathrm{CA}=$ Nilai prosentase agregat kasar tertahan saringan No.8

$\mathrm{FA}=$ Nilai prosentase agregat halus lolos saringan

No.8 tertahan No.200

$\mathrm{FF} \quad=$ Nilai prosentase filler (tertahan saringan No.200)

$\mathrm{K}=$ Konstanta (kira-kira $0,5-1,0)$

Persamaan diatas diperoleh dari Pd-T-042005-B (Badan Litbang Departemen Pekerjaan Umum, 2005) yang digunakan untuk mencari kadar aspal tengah atau ideal.

\section{Berat Jenis Bulk dari Agregat Campuran}

Agregat yang digunakan untuk membentuk beton aspal padat, memiliki gradasi tertentu yang biasanya diperoleh dari pencampuran beberapa agregat total yang terdiri dari atas fraksi-fraksi agregat kasar, agregat halus dan bahan pengisi yang masing-masing mempunyai berat jenis yang berbeda, maka berat jenis bulk (Gab) agregat total dapat dihitung sebagai berikut:

$$
G_{s b}=\frac{P_{1}+P_{2}+\ldots .+P_{n}}{\frac{P_{1}}{G_{1}}+\frac{P_{2}}{G_{2}}+\ldots \ldots . . \frac{P_{n}}{G_{n}}}
$$

Keterangan :

$$
\begin{aligned}
& \text { Gsb = Berat jenis bulk total agregat } \\
& \mathrm{P} 1+\mathrm{P} 2+\ldots+\mathrm{Pn}=\text { Persentase masing-masing fraksi } \\
& \text { agregat } \\
& \mathrm{G} 1+\mathrm{G} 2+\ldots \quad+\mathrm{Gn} \quad=\text { Berat jenis bulk masing-masing } \\
& \text { fraksi agregat }
\end{aligned}
$$

\section{Berat Jenis Efektif Agregat Campuran}

Berat jenis maksimum dari beton aspal yang belum dipadatkan $(\mathrm{Gmm})$, dapat ditentukan di Laboratorium sesuai AASHTO T 209-90.

$$
G_{s e}=\frac{P_{1}+P_{2}+\ldots .+P_{n}}{\frac{P_{1}}{G_{1}}+\frac{P_{2}}{G_{2}}+\ldots \ldots . . \frac{P_{n}}{G_{n}}}
$$

Keterangan :

Gse

$\mathrm{P} 1+\mathrm{P} 2+\ldots+\mathrm{Pn}$

$\mathrm{G} 1+\mathrm{G} 2+\ldots+\mathrm{Gn}$
= Berat jenis bulk total agregat

= Persentase masing-masing fraksi agregat

= Berat jenis bulk masing-masing fraksi agregat 


\section{Berat Jenis Maksimum Campuran}

Berat jenis maksimum campuran (Gmm) pada masingmasing kadar aspal diperlukan untuk menghitung kadar rongga masing-masing kadar aspal. Ketelitian hasil uji terbaik adalah bila kadar aspal campuran mendekati kadar aspal optimum. Sebaliknya pengujian berat jenis maksimum dilakukan dengan benda uji sebanyak minimum dua buah (duplikat) atau tiga buah (triplikat).

Selanjutnya Berat Jenis Maksimum (Gmm) campuran untuk masing-masing kadar aspal dapt dihitung menggunakan berat jenis efektif (Gse) rata-rata sebagai berikut:

$$
G_{m m}=\frac{P_{m m}}{\frac{P_{s}}{G_{s e}}+\frac{P_{b}}{G_{b}}}
$$

Keterangan :

$$
\begin{aligned}
& \text { Gmm Berat jenis maksimum campuran, rongga } \\
& \text { = udara nol } \\
& \text { Pmm = Persen berat total campuran }=100 \\
& \text { Kadar agregat persen terhadap VMA berat } \\
& \text { Ps = total campuran VFB } \\
& \text { Kadar aspal, persen terhadap berat total } \\
& \mathrm{Pb}=\text { campuran } \\
& \text { Gse = Berat jenis efektif agregat } \\
& \mathrm{Gb} \quad=\text { Berat jenis aspal }
\end{aligned}
$$

\section{Penyerapan Aspal}

Penyerapan aspal dinyatakan dalam persen terhadap berat agregat total, tidak terhadap berat campuran. Perhitungan penyerapan aspal (Pba) adalah sebagai berikut:

$$
P_{a b}=100 \frac{G_{s e}+G_{a b}}{G_{s e}+G_{s e}} G_{b}
$$

\section{Keterangan :}

$$
\begin{array}{ll}
\mathrm{Pab} & =\text { Penyerapan aspal, persen total agregat } \\
\mathrm{Gab} & =\text { Berat jenis bulk agregat } \\
\mathrm{Gse} & =\text { Berat jenis efektif } \\
\mathrm{Gb} & =\text { Berat jenis aspal }
\end{array}
$$

\section{Kadar Aspal Efektif}

Kadar aspal efektif (Pbe) campuran beraspal adalah kadar aspal total dikurangi jumlah aspal yang terserap oleh partikel agregat. Kadar aspal efektif ini akan menyelimuti permukaan agregat bagian luar yang pada akhirnya akan menentukan kinerja perkerasaan beraspal. Rumus kadar aspal efektif adalah :

$P_{b e}=P_{b} \frac{P_{a b}}{100} P_{s}$

Keterangan :

$\mathrm{P}_{\text {be }}=$ Kadar aspal efektif, persen total campuran

$\mathrm{P}_{\mathrm{b}}=$ Kadar aspal, persen total campuran

$\mathrm{P}_{\mathrm{ab}}=$ Penyerapan aspal, persen total campuran

$\mathrm{P}_{\mathrm{s}}=$ Kadar agregat, persen total campuran

\section{Rongga di Antara Mineral Agregat (VMA)}

Rongga antar mineral agregat (VMA) adalah ruang rongga diantara partikel agregat pada suatu perkerasan, termasuk rongga udara dan volume aspal efektif (tidak termasuk volume aspal yang diserap agregat). VMA dihitung berdasarkan berat jenis bulk (Gsb) agregat dan dinyatakan sebagai persen volume bulk campuran yang dipadatkan. VMA dapat dihitung pula terhadap berat campuran total atau terhadap berat agregat total. Perhitungan VMA terhadap campuran adalah dengan rumus berikut :

1) Terhadap berat campuran total

$$
V M A=100 \frac{P_{s b} \times P_{s}}{G_{s b}}
$$

Keterangan :

VMA = Rongga udara pada mineral agregat, prosentase dari volume total,(\%)

$\mathrm{Gmb}=$ Berat jenis campuran setelah pemadatan ( $\mathrm{gr} / \mathrm{cc})$

Gsb = Berat jenis bulk agregat, $(\mathrm{gr} / \mathrm{cc})$

$\mathrm{P}_{\mathrm{s}} \quad=$ Kadar agregat, persen terhadap berat total campuran, (\%)

2) Terhadap berat agregat total

$$
V M A=100-\frac{G_{m b}}{G_{s b}} \times \frac{100}{\left(100+P_{b}\right)}
$$

Keterangan :

$$
\begin{array}{ll}
\mathrm{VMA} & =\begin{array}{l}
\text { Rongga udara pada mineral agregat, } \\
\text { prosentase dari volume total, }(\%)
\end{array} \\
\mathrm{Gmb} & =\begin{array}{l}
\text { Berat jenis campuran setelah } \\
\text { pemadatan (gr/cc) }
\end{array} \\
\mathrm{Gsb} & =\begin{array}{l}
\text { Berat jenis bulk agregat, (gr/cc) } \\
\mathrm{P}_{\mathrm{b}}
\end{array} \quad \text { Kadar aspal, persen total campuran, }
\end{array}
$$
(\%)

\section{Rongga di Dalam Campuran (VIM)}

Rongga udara dalam campuran VIM dalam campuran perkerasan beraspal terdiri atas ruang udara diantara partikel agregat yang terselimuti aspal. Volume rongga udara dalam campuran dapat ditentukan dengan rumus berikut:

$$
V I M=100 \frac{G_{m m}-P_{m b}}{G_{m m}}
$$

Keterangan :

VIM = Rongga udara pada campuran setelah pemadatan, prosentase dari volume total, (\%)

$\mathrm{Gmb}=$ Berat jenis campuran setelah pemadatan (gr/cc)

Gmm = Berat jenis campuran maksimum teoritis setelah pemadatan ( $\mathrm{gr} / \mathrm{cc})$

\section{Stabilitas}

Nilai stabilitas diperoleh berdasarkan nilai masingmasing yang ditunjukkan oleh jarum dial. Untuk nilai stabilitas, nilai yang ditunjukkan pada jarum dial perlu dikonversikan terhadap alat Marshall. Selain itu pada umumnya alat Marshall yang digunakan bersatuan Lbf (pound force), sehingga harus disesuaikan satuannya terhadap satuan kilogram. Selanjutnya nilai tersebut juga harus disesuaikan dengan angka koreksi 
terhadap ketebalan atau volume benda uji.

\section{Rongga Udara yang Terisi Aspal (VFB)}

Rongga terisi aspal (VFB) adalah persen rongga yang terdapat diantara partikel agregat (VMB) yang terisi oleh aspal, tidak termasuk aspal yang diserap oleh agregat. Rumus adalah sebagai berikut:

$V F B=\frac{100\left(V M A-V_{a}\right)}{V M A}$

Keterangan :

VFB = Rongga udara yang terisi aspal, prosentase dari VMA, (\%)

VMA = Rongga udara pada mineral agregat, prosentase dari volume total, (\%)

$\mathrm{V}_{\mathrm{a}} \quad=$ Rongga udara pada campuran setelah pemadatan, prosentase dari volume total, (\%)

\section{Flow}

Nilai flow berdasarkan nilai masing-masing yang ditunjukkan oleh jarum dial. Hanya saja untuk alat uji jarum dial flow biasanya sudah dalam satuan $\mathrm{mm}$ (milimeter), sehingga tidak perlu dikonversikan lebih lanjut.

\section{Marshall}

Hasil bagi Marshall/Marshall Quotient (MQ) merupakan hasil pembagian dari stabilitas dengan kelelehan. Sifat Marshall tersebut dapat dihitung dengan menggunakan rumus berikut:

$M Q=\frac{M S}{M F}$

Keterangan :

$\mathrm{MQ}=$ Marshall Quotient, $(\mathrm{kg} / \mathrm{mm})$

MS = Marshall Stability, $(\mathrm{kg})$

MF = Flow Marshall, $(\mathrm{mm})$

\section{HASIL DAN PEMBAHASAN}

Setelah dilakukan beberapa pengujian mulai dari pengujian aspal dan material agregat (agregat kasar, sedang, dan halus) dan juga setelah dibuat benda uji (briket) sebanyak \pm 45 benda uji (15 benda uji dengan material Gunung Bitung, 15 benda uji dengan material Gunung rumpin, dan 15 benda uji dengan material Gunung Sudamanik) barulah dilakukan analisis dan pembahasan terhadap hasil yang telah didapatkan. Berikut ini merupakan analisis hasil dari pengujian material yang akan digunakan dalam pembuatan campuran aspal berdasarkan spesifikasi Kementrian Pekerjaan Umum Direktorat Jenderal Bina Marga, Revisi III, 2010.

\section{Hasil Pengujian Material}

Tabel 2. Hasil Pengujian Analisa Saring Agregat

\begin{tabular}{|c|c|c|c|c|}
\hline \multicolumn{5}{|c|}{ Material Gunung Bitung } \\
\hline \multicolumn{2}{|c|}{$\begin{array}{l}\text { Ukuran } \\
\text { Saringan }\end{array}$} & \multicolumn{3}{|c|}{ Rata-rata Lolos (\%) } \\
\hline Inch & $\mathrm{mm}$ & $\begin{array}{l}\text { Agregat } \\
\text { Kasar }\end{array}$ & $\begin{array}{l}\text { Agregat } \\
\text { Sedang }\end{array}$ & Agregat Halus \\
\hline $11 / 2$ & 37,9 & - & - & - \\
\hline 1 & 25,4 & - & - & - \\
\hline $3 / 4$ & 19,1 & 100 & - & - \\
\hline $1 / 2$ & 12,7 & 99,80 & - & - \\
\hline $3 / 8$ & 9,52 & 67,84 & 100,00 & 100,00 \\
\hline No. 4 & 4,75 & 3,40 & 77,48 & 99,94 \\
\hline No. 8 & 2,38 & 2,18 & 17,13 & 88,40 \\
\hline No. 16 & 1,17 & 1,74 & 6,36 & 62,43 \\
\hline No. 30 & 0,59 & 1,69 & 5,43 & 44,57 \\
\hline No. 50 & 0,29 & 1,54 & 3,68 & 30,34 \\
\hline No. 100 & 0,14 & 1,25 & 2,52 & 18,75 \\
\hline No. 200 & 0,075 & 0,83 & 1,04 & 12,14 \\
\hline \multicolumn{5}{|c|}{ Material Gunung Rumpin } \\
\hline \multicolumn{2}{|c|}{$\begin{array}{c}\text { Ukuran } \\
\text { Saringan }\end{array}$} & \multicolumn{3}{|c|}{ Rata-rata Lolos (\%) } \\
\hline Inch & $\mathbf{m m}$ & $\begin{array}{l}\text { Agregat } \\
\text { Kasar }\end{array}$ & $\begin{array}{l}\text { Agregat } \\
\text { Sedang }\end{array}$ & Agregat Halus \\
\hline $11 / 2$ & 37,9 & - & - & - \\
\hline 1 & 25,4 & - & - & - \\
\hline $3 / 4$ & 19,1 & 100 & - & - \\
\hline $1 / 2$ & 12,7 & 100 & - & - \\
\hline $3 / 8$ & 9,52 & 68,55 & 100,00 & 100,00 \\
\hline No. 4 & 4,75 & 11,87 & 73,13 & 99,95 \\
\hline No. 8 & 2,38 & 2,53 & 15,91 & 92,33 \\
\hline No. 16 & 1,17 & 1,46 & 4,01 & 64,28 \\
\hline No. 30 & 0,59 & 1,36 & 1,91 & 46,70 \\
\hline No. 50 & 0,29 & 1,21 & 1,92 & 31,90 \\
\hline No. 100 & 0,14 & 1,16 & 1,75 & 18,78 \\
\hline No. 200 & 0,075 & 1,07 & 1,42 & 12,56 \\
\hline \multicolumn{5}{|c|}{ Material Gunung Sudamanik } \\
\hline \multicolumn{2}{|c|}{$\begin{array}{c}\text { Ukuran } \\
\text { Saringan }\end{array}$} & \multicolumn{3}{|c|}{ Rata-rata Lolos (\%) } \\
\hline Inch & $\mathbf{m m}$ & $\begin{array}{l}\text { Agregat } \\
\text { Kasar }\end{array}$ & $\begin{array}{l}\text { Agregat } \\
\text { Sedang }\end{array}$ & Agregat Halus \\
\hline $1 \frac{1 / 2}{2}$ & 37,9 & - & - & - \\
\hline 1 & 25,4 & - & - & - \\
\hline $3 / 4$ & 19,1 & 100 & - & - \\
\hline $1 / 2$ & 12,7 & 100 & - & - \\
\hline $3 / 8$ & 9,52 & 68,36 & 100,00 & 100,00 \\
\hline No. 4 & 4,75 & 11,36 & 72,90 & 99,95 \\
\hline No. 8 & 2,38 & 1,90 & 15,44 & 92,35 \\
\hline No. 16 & 1,17 & 0,90 & 3,22 & 64,33 \\
\hline No. 30 & 0,59 & 0,86 & 1,45 & 46,72 \\
\hline No. 50 & 0,29 & 0,81 & 1,31 & 31,89 \\
\hline No. 100 & 0,14 & 0,75 & 1,21 & 18,91 \\
\hline No. 200 & 0,075 & 0,60 & 0,98 & 12,48 \\
\hline
\end{tabular}

Tabel 3. Proporsi Campuran Agregat

\begin{tabular}{|c|c|c|c|}
\hline \multirow{4}{*}{$\begin{array}{c}\text { Mroporsi } \\
\text { Agregat }\end{array}$} & $\begin{array}{c}\text { Agregat } \\
\text { Kasar }\end{array}$ & $\begin{array}{c}\text { Agregat } \\
\text { Sedang }\end{array}$ & Agregat Halus \\
\cline { 2 - 4 } & $38 \%$ & $17 \%$ & $45 \%$ \\
\hline Total & \multicolumn{3}{|c|}{$100 \%$} \\
\hline \multicolumn{4}{|c|}{ Material Gunung Rumpin } \\
\hline \multirow{2}{*}{$\begin{array}{c}\text { Proporsi } \\
\text { Agregat }\end{array}$} & $\begin{array}{c}\text { Agregat } \\
\text { Kasar }\end{array}$ & $\begin{array}{c}\text { Agregat } \\
\text { Sedang }\end{array}$ & Agregat Halus \\
\cline { 2 - 4 } & $38 \%$ & $17 \%$ & $45 \%$ \\
\hline Total & \multicolumn{3}{|c|}{$100 \%$} \\
\hline \multicolumn{4}{|c|}{ Material Gunung Sudamanik } \\
\hline \multirow{2}{*}{$\begin{array}{c}\text { Proporsi } \\
\text { Agregat }\end{array}$} & $\begin{array}{c}\text { Agregat } \\
\text { Kasar }\end{array}$ & $\begin{array}{c}\text { Agregat } \\
\text { Sedang }\end{array}$ & Agregat Halus \\
\cline { 2 - 4 } & $38 \%$ & $17 \%$ & $45 \%$ \\
\hline Total & \multicolumn{3}{c}{$100 \%$} \\
\hline
\end{tabular}


Tabel 4. Gradasi Agregat Gabungan (Gunung Bitung)

\begin{tabular}{|c|c|c|c|c|c|c|c|}
\hline \multicolumn{2}{|c|}{ Ukuran Saringan } & \multicolumn{3}{|c|}{ Persentase Agregat (\%) } & \multirow{2}{*}{ Agregat Gabungan } & \multirow{2}{*}{ Spesifikasi } & \multirow{2}{*}{ Status } \\
\hline Inch & $\mathbf{m m}$ & Agregat Kasar & Agregat Sedang & Agregat Halus & & & \\
\hline $1 \frac{1 / 2}{2}$ & 37,9 & - & - & - & - & - & - \\
\hline 1 & 25,4 & - & - & - & - & - & - \\
\hline $3 / 4$ & 19,1 & 38 & 17 & 45 & 100 & 100 & Memenuhi \\
\hline $1 / 2$ & 12,7 & 37,92 & 17 & 45 & 99,92 & $90-100$ & Memenuhi \\
\hline $3 / 8$ & 9,52 & 25,78 & 17 & 45 & 87,78 & $77-90$ & Memenuhi \\
\hline No. 4 & 4,75 & 1,29 & 13,17 & 44,98 & 59,44 & 53-69 & Memenuhi \\
\hline No. 8 & 2,38 & 0,83 & 2,91 & 39,78 & 43,52 & $33-53$ & Memenuhi \\
\hline No. 16 & 1,17 & 0,66 & 1,08 & 28,09 & 29,84 & $21-40$ & Memenuhi \\
\hline No. 30 & 0,59 & 0,64 & 0,92 & 20,06 & 21,62 & $14-30$ & Memenuhi \\
\hline No. 50 & 0,29 & 0,59 & 0,63 & 13,65 & 14,87 & $9-22$ & Memenuhi \\
\hline No. 100 & 0,14 & 0,48 & 0,43 & 8,44 & 9.34 & 6-15 & Memenuhi \\
\hline No. 200 & 0,075 & 0,31 & 0,18 & 5,46 & 5,95 & $4-9$ & Memenuhi \\
\hline
\end{tabular}

Tabel 5. Gradasi Agregat Gabungan (Gunung Rumpin)

\begin{tabular}{|c|c|c|c|c|c|c|c|}
\hline \multicolumn{2}{|c|}{ Ukuran Saringan } & \multicolumn{3}{|c|}{ Persentase Agregat (\%) } & \multirow{2}{*}{$\begin{array}{c}\text { Agregat } \\
\text { Gabungan }\end{array}$} & \multirow[b]{2}{*}{ Spesifikasi } & \multirow[b]{2}{*}{ Status } \\
\hline Inch & $\mathbf{m m}$ & $\begin{array}{c}\text { Agregat } \\
\text { Kasar }\end{array}$ & $\begin{array}{l}\text { Agregat } \\
\text { Sedang }\end{array}$ & $\begin{array}{c}\text { Agregat } \\
\text { Halus }\end{array}$ & & & \\
\hline $1 \frac{1 / 2}{2}$ & 37,9 & - & - & - & - & - & - \\
\hline 1 & 25,4 & - & - & - & - & - & - \\
\hline $3 / 4$ & 19,1 & 38 & 17 & 45 & 100 & 100 & Memenuhi \\
\hline $1 / 2$ & 12,7 & 38 & 17 & 45 & 100 & $90-100$ & Memenuhi \\
\hline $3 / 8$ & 9,52 & 26,05 & 17 & 45 & 88,05 & $77-90$ & Memenuhi \\
\hline No. 4 & 4,75 & 4,51 & 12,43 & 44,98 & 61,92 & $53-69$ & Memenuhi \\
\hline No. 8 & 2,38 & 0,96 & 2,70 & 41,55 & 45,22 & $33-53$ & Memenuhi \\
\hline No. 16 & 1,17 & 0,56 & 0,68 & 28,93 & 30,17 & $21-40$ & Memenuhi \\
\hline No. 30 & 0,59 & 0,52 & 0,33 & 21,02 & 21,86 & $14-30$ & Memenuhi \\
\hline No. 50 & 0,29 & 0,46 & 0,33 & 14,36 & 15,14 & $9-22$ & Memenuhi \\
\hline No. 100 & 0,14 & 0,44 & 0,30 & 8,45 & 9,19 & $6-15$ & Memenuhi \\
\hline No. 200 & 0,075 & 0,41 & 0,24 & 5,65 & 6,30 & $4-9$ & Memenuhi \\
\hline
\end{tabular}

Tabel 6. Gradasi Agregat Gabungan (Gunung Sudamanik)

\begin{tabular}{|c|c|c|c|c|c|c|c|}
\hline \multicolumn{2}{|c|}{ Ukuran Saringan } & \multicolumn{3}{|c|}{ Persentase Agregat (\%) } & \multirow[b]{2}{*}{$\begin{array}{c}\text { Agregat } \\
\text { Gabungan }\end{array}$} & \multirow[b]{2}{*}{ Spesifikasi } & \multirow[b]{2}{*}{ Status } \\
\hline Inch & $\mathbf{m m}$ & $\begin{array}{c}\text { Agregat } \\
\text { Kasar }\end{array}$ & $\begin{array}{l}\text { Agregat } \\
\text { Sedang }\end{array}$ & $\begin{array}{c}\text { Agregat } \\
\text { Halus }\end{array}$ & & & \\
\hline $1 \frac{1 / 2}{2}$ & 37,9 & - & - & - & - & - & - \\
\hline $3 / 4$ & 19,1 & 38 & 17 & 45 & 100 & 100 & Memenuhi \\
\hline $1 / 2$ & 12,7 & 38 & 17 & 45 & 100 & $90-100$ & Memenuhi \\
\hline $3 / 8$ & 9,52 & 25,98 & 17 & 45 & 87,98 & $77-90$ & Memenuhi \\
\hline No. 16 & 1,17 & 0,34 & 0,55 & 28,95 & 29,84 & $21-40$ & Memenuhi \\
\hline No. 30 & 0,59 & 0,33 & 0,25 & 21,02 & 21,60 & $14-30$ & Memenuhi \\
\hline No. 50 & 0,29 & 0,31 & 0,22 & 14,35 & 14,88 & $9-22$ & Memenuhi \\
\hline No. 100 & 0,14 & 0,29 & 0,21 & 8,51 & 9,00 & $6-15$ & Memenuhi \\
\hline No. 200 & 0,075 & 0,23 & 0,17 & 5,61 & 6,01 & $4-9$ & Memenuhi \\
\hline
\end{tabular}

Hasil dari pengujian gradasi agregat dari Gunung Bitung, Gunung Rumpin, dan Gunung Sudamanik setelah disajikan dalam bentuk tabel, maka disajikan dalam bentuk grafik, dalam bentuk grafik inilah dapat diketahui gradasi tersebut memenuhi spesifikasi atau tidak. Dapat dilihat pada Gambar 2, 3, dan 4, dimana pada grafik tersebut didapatkan bahwa gradasi agregat gabungan (gradasi menerus/well graded) mulai dari agregat dari Gunung Bitung sampai dengan agregat dari Gunung Sudamanik memenuhi spesifikasi yang telah ditetapkan oleh Bina Marga.

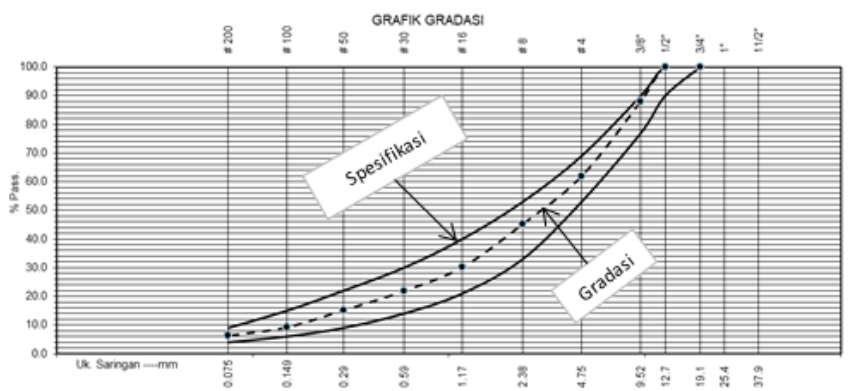

Gambar 2. Grafik Spesifikasi Agregat (Gunung Bitung)

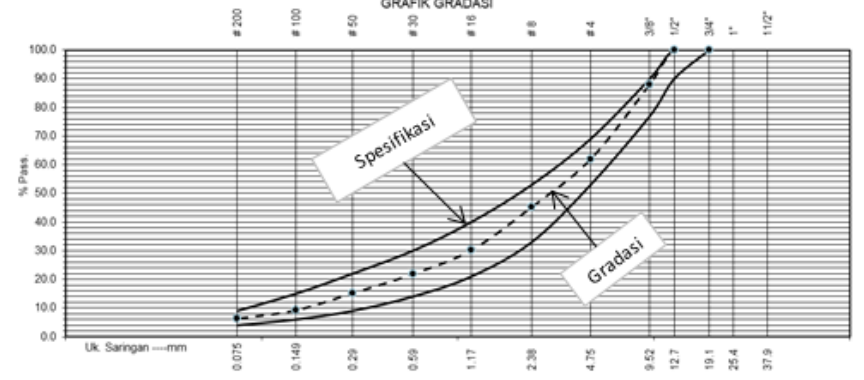

Gambar 3. Grafik Spesifikasi Agregat (Gunung Rumpin)

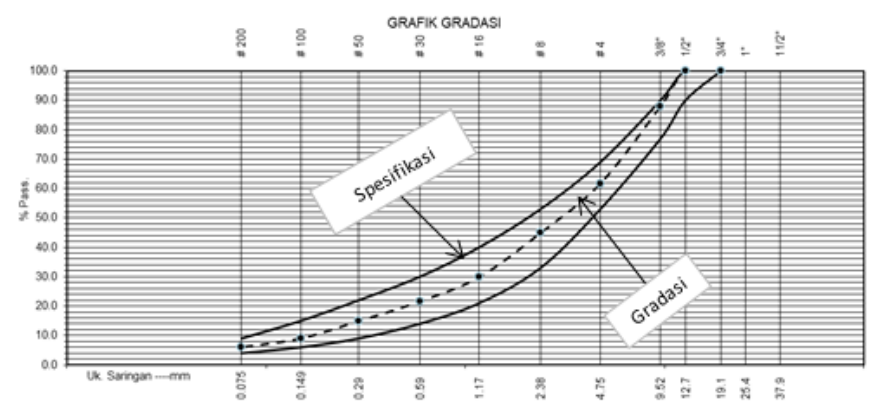

Gambar 4. Grafik Spesifikasi Agregat (Gunung Sudamanik) 
Setelah didapatkan gradasi agregat untuk campuran aspal dengan material dari Gunung Bitung, Gunung Rumpin, dan Gunung Sudamanik barulah dapat dilakukan penentuan kadar aspal yang akan digunakan. Penentuan kadar aspal ini menggunakan persamaan (1) dimana dalam formula untuk mencari kadar aspal rencana tersebut diperlukan data dari analisa saringan. Kadar aspal rencana untuk campuran aspal dengan material dari Gunung Bitung, Gunung Rumpin, dan Gunung Sudamanik dapat dilihat pada Tabel 9 berikut:

Tabel 7. Kadar Aspal Rencana

\begin{tabular}{|c|l|c|c|c|}
\hline No. & $\begin{array}{c}\text { Kadar Aspal } \\
\text { (\%) }\end{array}$ & $\begin{array}{c}\text { Material } \\
\text { Gunung } \\
\text { Bitung }\end{array}$ & $\begin{array}{c}\text { Material } \\
\text { Gunung } \\
\text { Bitung }\end{array}$ & $\begin{array}{c}\text { Material } \\
\text { Gunung } \\
\text { Bitung }\end{array}$ \\
\hline 1. & $\mathrm{~Pb}-1 \%$ & 5 & 5 & 5 \\
\hline 2. & $\mathrm{~Pb}-0,5 \%$ & 5,5 & 5,5 & 5,5 \\
\hline 3. & $\mathrm{~Pb}$ & 6 & 6 & 6 \\
\hline 4. & $\mathrm{~Pb}+0,5 \%$ & 6,5 & 6,5 & 6,5 \\
\hline 5. & $\mathrm{~Pb}+1 \%$ & 7 & 7 & 7 \\
\hline
\end{tabular}

Setelah kadar aspal rencana didapatkan (Tabel 9) maka dapat langsung dibuat benda uji. Di bawah ini merupakan nilai dari karakteristik marshall hasil pengujian benda uji (briket) :

Tabel 8. Hasil Pengujian Marshall Campuran Aspal (Gunung Bitung)

\begin{tabular}{|c|c|c|c|c|c|c|}
\hline \multirow{2}{*}{\multicolumn{2}{|c|}{$\begin{array}{c}\text { Nilai Karakteristik } \\
\text { Marshall }\end{array}$}} & \multicolumn{5}{|c|}{ Kadar Aspal (\%) } \\
\hline & & 5,0 & 5,5 & 6,0 & 6,5 & 7,0 \\
\hline \multirow{3}{*}{$\begin{array}{l}\text { VIM } \\
(\%)\end{array}$} & Hasil & 7,55 & 6,71 & 5,53 & 5,37 & 4,75 \\
\hline & Syarat & \multicolumn{5}{|c|}{$3-5$} \\
\hline & Status & $\begin{array}{l}\text { TIDAK } \\
\text { OK }\end{array}$ & $\begin{array}{l}\text { TIDAK } \\
\text { OK }\end{array}$ & $\begin{array}{l}\text { TIDAK } \\
\text { OK }\end{array}$ & $\begin{array}{l}\text { TIDAK } \\
\text { OK }\end{array}$ & OK \\
\hline \multirow{3}{*}{$\begin{array}{l}\text { VMA } \\
(\%)\end{array}$} & Hasil & 15,41 & 15,69 & 15,67 & 15,43 & 17,08 \\
\hline & Syarat & \multicolumn{5}{|c|}{ Min 15} \\
\hline & Status & OK & OK & OK & OK & OK \\
\hline \multirow{3}{*}{$\begin{array}{l}\text { VFB } \\
(\%)\end{array}$} & Hasil & 55,59 & 61,26 & 67,71 & 73,20 & 77,07 \\
\hline & Syarat & \multicolumn{5}{|c|}{$\operatorname{Min} 65$} \\
\hline & Status & $\begin{array}{l}\text { TIDAK } \\
\text { OK }\end{array}$ & $\begin{array}{l}\text { TIDAK } \\
\text { OK }\end{array}$ & OK & OK & OK \\
\hline \multirow{3}{*}{$\begin{array}{l}\text { Stabilitas } \\
\text { (kg) }\end{array}$} & Hasil & 996 & 1046 & 976 & 1031 & 1021 \\
\hline & Syarat & \multicolumn{5}{|c|}{$\operatorname{Min} 800$} \\
\hline & Status & OK & OK & OK & OK & OK \\
\hline \multirow{3}{*}{$\begin{array}{l}\text { Flow } \\
(\mathrm{mm})\end{array}$} & Hasil & 2,53 & 2,76 & 2,84 & 3,30 & 3,38 \\
\hline & Syarat & \multicolumn{5}{|c|}{$2-4$} \\
\hline & Status & OK & OK & OK & OK & OK \\
\hline \multirow{3}{*}{$\begin{array}{c}\text { MQ } \\
(\mathrm{Kg} / \mathrm{mm})\end{array}$} & Hasil & 393 & 379 & 344 & 312 & 304 \\
\hline & Syarat & \multicolumn{5}{|c|}{ Min 250 kg/mm } \\
\hline & Status & OK & OK & OK & OK & OK \\
\hline
\end{tabular}

Tabel 9. Hasil Pengujian Marshall Campuran Aspal (Gunung Rumpin)

\begin{tabular}{|c|c|c|c|c|c|c|}
\hline \multirow{2}{*}{\multicolumn{2}{|c|}{$\begin{array}{c}\text { Nilai Karakteristik } \\
\text { Marshall }\end{array}$}} & \multicolumn{5}{|c|}{ Kadar Aspal (\%) } \\
\hline & & 5,0 & 5,5 & 6,0 & 6,5 & 7,0 \\
\hline \multirow{3}{*}{$\begin{array}{l}\text { VIM } \\
\text { (\%) }\end{array}$} & Hasil & 7,23 & 4,31 & 4,12 & 2,86 & 1,85 \\
\hline & Syarat & \multicolumn{5}{|c|}{$3-5$} \\
\hline & Status & $\begin{array}{c}\text { TIDAK } \\
\text { OK }\end{array}$ & OK & OK & $\begin{array}{c}\text { TIDAK } \\
\text { OK }\end{array}$ & $\begin{array}{c}\text { TIDAK } \\
\text { OK }\end{array}$ \\
\hline \multirow{3}{*}{$\begin{array}{l}\text { VMA } \\
\text { (\%) }\end{array}$} & Hasil & 17,50 & 15,96 & 16,84 & 16,91 & 17,25 \\
\hline & Syarat & \multicolumn{5}{|c|}{ Min 15} \\
\hline & Status & OK & OK & OK & OK & OK \\
\hline \multirow{3}{*}{$\begin{array}{l}\text { VFB } \\
\text { (\%) }\end{array}$} & Hasil & 58,92 & 73,07 & 75,54 & 83,21 & 89,29 \\
\hline & Syarat & \multicolumn{5}{|c|}{ Min 65} \\
\hline & Status & $\begin{array}{c}\text { TIDAK } \\
\text { OK }\end{array}$ & OK & OK & OK & OK \\
\hline \multirow{3}{*}{$\begin{array}{l}\text { Stabilitas } \\
\quad(\mathbf{k g})\end{array}$} & Hasil & 996 & 1064 & 1141 & 1213 & 1310 \\
\hline & Syarat & \multicolumn{5}{|c|}{ Min 800} \\
\hline & Status & OK & OK & OK & OK & OK \\
\hline
\end{tabular}

\begin{tabular}{|c|c|c|c|c|c|c|}
\hline \multirow{2}{*}{$\begin{array}{c}\text { Nilai Karakteristik } \\
\text { Marshall }\end{array}$} & \multicolumn{6}{|c|}{ Kadar Aspal (\%) } \\
\cline { 2 - 7 } & $\mathbf{5 , 0}$ & $\mathbf{5 , 5}$ & $\mathbf{6 , 0}$ & $\mathbf{6 , 5}$ & $\mathbf{7 , 0}$ \\
\hline \multirow{3}{*}{$\begin{array}{c}\text { Flow } \\
(\mathbf{m m})\end{array}$} & Hasil & 2,96 & 3,73 & 3,64 & 4,45 & 4,45 \\
\cline { 2 - 7 } & Syarat & \multicolumn{7}{|c|}{$2-4$} \\
\cline { 2 - 7 } & Status & OK & OK & OK & $\begin{array}{c}\text { TIDAK } \\
\text { OK }\end{array}$ & $\begin{array}{c}\text { TIDAK } \\
\text { OK }\end{array}$ \\
\hline \multirow{3}{*}{ MQ (Kg/mm) } & Hasil & 341 & 310 & 319 & 273 & 300 \\
\cline { 2 - 7 } & Syarat & \multicolumn{7}{|c|}{$250 \mathrm{~kg} / \mathrm{mm}$} \\
\cline { 2 - 7 } & Status & OK & OK & OK & OK & OK \\
\hline
\end{tabular}

Tabel 10. Hasil Pengujian Marshall Campuran Aspal (Gunung Sudamanik)

\begin{tabular}{|c|c|c|c|c|c|c|}
\hline \multirow{2}{*}{\multicolumn{2}{|c|}{$\begin{array}{c}\text { Nilai Karakteristik } \\
\text { Marshall }\end{array}$}} & \multicolumn{5}{|c|}{ Kadar Aspal (\%) } \\
\hline & & 5,0 & 5,5 & 6,0 & 6,5 & 7,0 \\
\hline \multirow{3}{*}{$\begin{array}{l}\text { VIM } \\
\text { (\%) }\end{array}$} & Hasil & 7,35 & 6,87 & 5,97 & 4,12 & 3,86 \\
\hline & Syarat & \multicolumn{5}{|c|}{$3-5$} \\
\hline & Status & $\begin{array}{c}\text { TIDAK } \\
\text { OK }\end{array}$ & $\begin{array}{c}\text { TIDAK } \\
\text { OK }\end{array}$ & $\begin{array}{c}\text { TIDAK } \\
\text { OK }\end{array}$ & OK & OK \\
\hline \multirow{3}{*}{$\begin{array}{l}\text { VMA } \\
\text { (\%) }\end{array}$} & Hasil & 18,22 & 18,43 & 18,29 & 17,26 & 17,66 \\
\hline & Syarat & \multicolumn{5}{|c|}{ Min 15} \\
\hline & Status & OK & OK & OK & OK & OK \\
\hline \multirow{3}{*}{$\begin{array}{l}\text { VFB } \\
\text { (\%) }\end{array}$} & Hasil & 59,64 & 62,77 & 67,43 & 76,35 & 78,20 \\
\hline & Syarat & \multicolumn{5}{|c|}{ Min 65} \\
\hline & Status & $\begin{array}{c}\text { TIDAK } \\
\text { OK }\end{array}$ & $\begin{array}{c}\text { TIDAK } \\
\text { OK }\end{array}$ & OK & OK & OK \\
\hline \multirow{3}{*}{$\begin{array}{l}\text { Stabilitas } \\
(\mathrm{kg})\end{array}$} & Hasil & 1006 & 986 & 1140 & 1233 & 1310 \\
\hline & Syarat & \multicolumn{5}{|c|}{ Min 800} \\
\hline & Status & OK & OK & OK & OK & OK \\
\hline \multirow{3}{*}{$\begin{array}{l}\text { Flow } \\
(\mathrm{mm})\end{array}$} & Hasil & 2,76 & 2,78 & 3,00 & 3,20 & 3,29 \\
\hline & Syarat & \multicolumn{5}{|c|}{$2-4$} \\
\hline & Status & OK & OK & $\mathrm{OK}$ & OK & OK \\
\hline \multirow{3}{*}{$M Q(\mathrm{Kg} / \mathrm{mm})$} & Hasil & 366 & 356 & 381 & 385 & 398 \\
\hline & Syarat & \multicolumn{5}{|c|}{$\operatorname{Min} 250 \mathrm{~kg} / \mathrm{mm}$} \\
\hline & Status & OK & OK & $\mathrm{OK}$ & OK & OK \\
\hline
\end{tabular}

Adapun pembahasan dari hasil pengujian marshall test/sifat karakteristik marshall adalah sebagai berikut:

1. Hubungan VIM (Voids In Mixture) dengan Kadar Aspal.

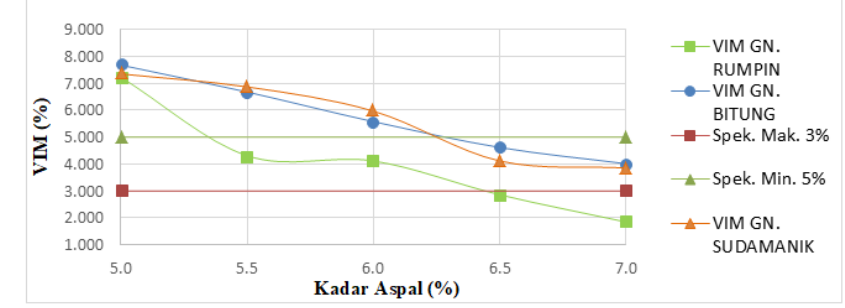

Gambar 5. Grafik VIM (3 - 5\%)

Pada Gambar 5 menunjukan bahwa nilai VIM dari tiga sumber material mengalami penurunan dan juga kenaikan yang signifikan dengan penambahan kadar aspal. Dari setiap campuran aspal dengan tiga material hanya dua kadar aspal pada setiap masing-masing sumber material yang memenuhi spesifikasi yaitu untuk campuran aspal dengan material Gunung Bitung hanya kadar aspal 6,5\% dan 7,0\%, untuk campuran aspal dengan material Gunung Rumpin hanya kadar aspal $5,5 \%$ dan $6,0 \%$, dan untuk campuran aspal dengan material Gunung Sudamanik hanya kadar aspal 6,5\% dan $7,0 \%$ dimana spesifikasi yang telah ditentukan ada pada batas minimum 3\% dan batas maksimum $5 \%$. 
2. Hubungan VMA (Voids In Mineral Agreggate) dengan Kadar Aspal.

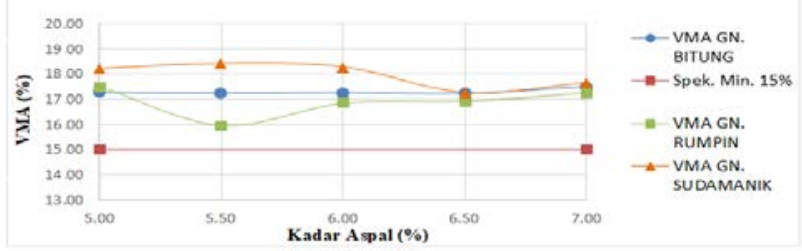

Gambar 6. Grafik VMA (minimal 15\%)

Pada Gambar 6 menunjukan nilai VMA dari tiga sumber material mengalami kenaikan maupun penurunan seiring dengan bertambahnya kadar aspal. Namun kenaikan ataupun penurunan yang terjadi ini memenuhi spesifikasi yang disyaratkan Kementerian Pekerjaan Umum Bina Marga Revisi III, 2010 yaitu 15\%. Maka dapat disimpulkan bahwa semua material yaitu material dari Gunung Bitung, Gunung Rumpin, dan gunung Sudamanik yang digunakan dengan lima kadar aspal memenuhi spesifikasi.

3. Hubungan VFB (Voids Filled With Bitumen) dengan Kadar Aspal.

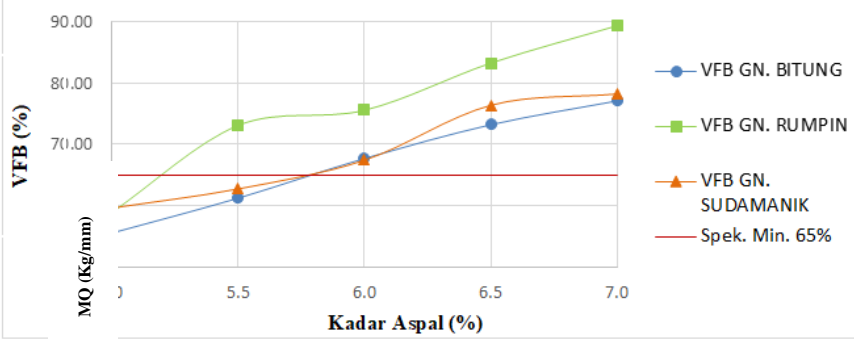

Gal...nur 7. Grafik VFB (minimal 65\%)

Pada Gambar 7 menunjukan terjadi kenaikan pada nilai VFB dari tiga sumber material. Namun, nilai VFB pada kadar aspal 5,0\% dan 5,5\% untuk material dari Gunung Bitung dan Gunung Sudamanik serta pada kadar aspal $5,0 \%$ untuk ,aterial Gunung Rumpin tidak memenuhi spesifikasi dimana batas minimum yaitu $65 \%$.

4. Hubungan Stabilitas dengan Kadar Aspal.

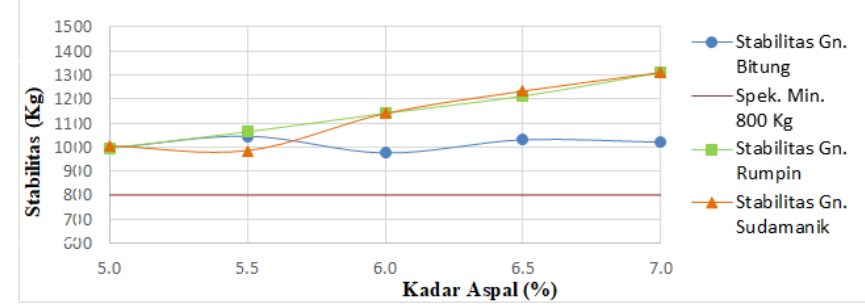

Gambar 8. Grafik Stabilitas (minimal $800 \mathrm{Kg}$ )

Pada Gambar 8 memnujukan bahwa nilai stabilitas pada campuran aspal dari tiga sumber material yaitu material dari Gunung Bitung, Gunung Rumpin, dan Gunung Sudamanik untuk setiap kadar aspal mengalami kenaikan dan penurunan. Namun, kenaikan dan penurunan yang terjadi memenuhi spesifikasi dimana nilai stabilitas pada setiap kadar aspal berada diatas nilai spesifikasi yaitu minimum $800 \mathrm{~kg}$.
5. Hubungan Flow dengan Kadar Aspal.

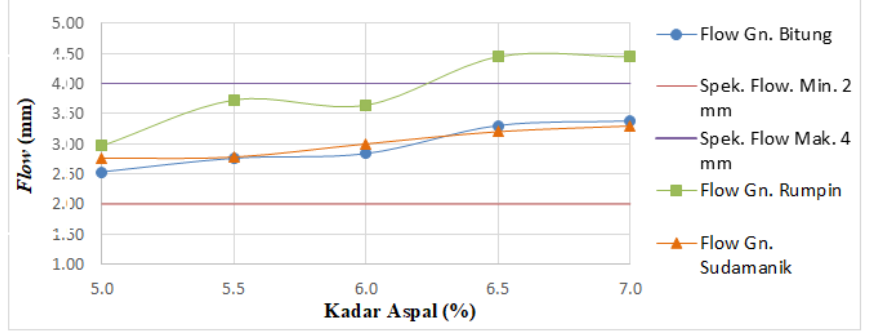

Gambar 9. Grafik Flow (2mm - 4mm)

Pada Gambar 9 nilai flow pada penggunaan campuran aspal material Gunung Rumpin untuk kadar aspal 6,5\% dan $7,0 \%$ tidak masuk dalam spesifikasi serta mengalami kenaikan dan penurunan seiring penambahan kadar aspal. Namun, untuk dua sumber material yaitu Gunung Bitung dan Gunung Rumpin semua kadar aspal masuk dalam spesifikasi dan memenuhi batas minimum $2 \mathrm{~mm}$ dan batas maksimum 4 $\mathrm{mm}$ sesuai dengan spesifikasi Kementerian Pekerjaan Umum Bina Marga Revisi III (2010).

6. Hubungan MQ (Marshall Quotient) dengan Kadar Aspal.

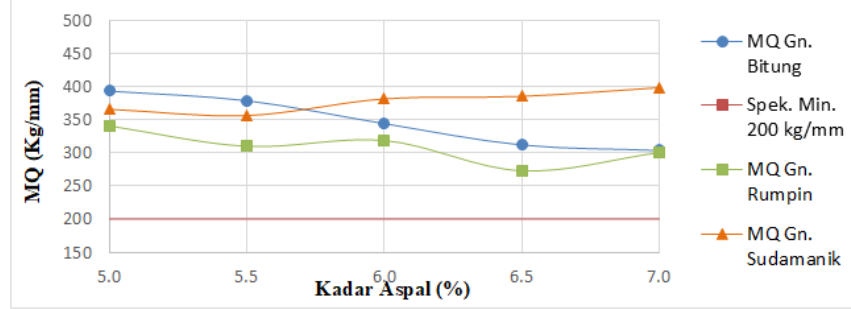

Gambar 10. Grafik Marshall Quotient (minimal 250 $\mathrm{Kg} / \mathrm{mm}$ )

Pada Gambar 10 nilai MQ untuk campuran aspal dari tiga sumber material mengalami penurunan dan kenaikan seiring dengan penambahan kadar aspal. Penurunan nilai $M Q$ ini, disebabkan nilai flow yang meningkat dengan kadar aspal yang meningkat pula begitu juga dengan nilai MQ yang mengalami kenaikan sebab nilai flow yang menurun dengan kadar aspal yang meningkat. Namun, nilai $\mathrm{MQ}$ dari campuran aspal dengan 3 material ini memenuhi spesifikasi sesuai dengan Kementerian Pekerjaan Umum Bina Marga Revisi III (2010) yaitu minimum yang harus dicapai adalah $200 \mathrm{~kg} / \mathrm{mm}$.

\section{KESIMPULAN}

Dari hasil pengujian didapatkan bahwa campuran aspal dengan material dari 3 sumber yang berbeda dilihat dari keseluruhan nilai karakteristik marshall nilainya berada diatas nilai dari spesifikasi ketentuan yang ditetapkan oleh Spesifikasi Bina Marga 2010, revisi III. Karakteristik marshall menunjukan bahwa campuran aspal dengan material Gunung Bitung dan Gunung Sudamanik memiliki kinerja yang lebih baik. Berdasarkan faktor kinerja campuran didapat kadar aspal optimum (KAO) yaitu Gunung Bitung (6,65\%), Gunung Rumpin (5,58\%), dan Gunung Sudamanik (6,65\%) sehingga dari hasil 
nilai analisis yang dilihat dari karakteristik marshall diketahui bahwa material dari Gunung Sudamanik memiliki stabilitas yang paling baik berdasarkan kadar aspal optimum (KAO), maka material dari Gunung Sudamanik dapat dijadikan acuan agregat lokal untuk penggunaan pembangnan infrastuktur di wilayahnya.

\section{UCAPAN TERIMA KASIH}

Penulis mengucapkan terimakasih yang sebesarbesarnya kepada AMP PT. Prayoga Pertambangan dan Energi yang telah memberikan kesempatan untuk melakukan penelitian di laboratorium PT. Prayoga Pertambangan dan Energi dan juga memberikan bahan material untuk keperluan Tugas Akhir.

Dan juga terimakasih kepada PT. Sudamanik dan PT. Lotus SG Lestari yang telah memberikan material agregat untuk penelitian ini.

\section{REFERENSI}

Anonim. (2017). Job Mixing Formula (JMF) AC-WC Grade C, AMP PT. Prayoga Pertambangan dan Energi, Bogor.

Arthur W, Peter S, Kendrick, Roy A, Malcolm C, . (2003). Teori dan Praktek, Edisi ke-4. Jakarta : Erlangga.

Departemen Pekerjaan Umum Direktorat Bina Marga. (2010). Buku XII Spesifikasi Teknis. Jakarta : Kementerian Pekerjaan Umum.

Hendrik, Arief S, Mashuri. (2014). Karakteristik Campuran Aspal Porus Dengan Agregat Dari Loli dan Taipa : Universitas Jember.

Shell Bitumen. (1990). The Shell Bitumen Hand Book, Shell Bitumen UK, UK.

SNI ASTM C117-2012. Metode Uji Bahan yang Lebih Halus dari Saringan 75 um (No. 200) dalam Agregat Mineral dengan Pencucian. Jakarta: Badan Standarisasi Nasional, 2012.

SNI ASTM C136-2012. Metode Uji Untuk Analisis Saringan Agregat Halus dan Agregat Kasar. Jakarta: Badan Standarisasi Nasional, 2012.

SNI 03-6723-2002. Spesifikasi Bahan Pengisi Pengisi Untuk Campuran Beraspal. Jakarta: Badan Standarisasi Nasional, 2002.

SNI 06-2489-1991. Metode Pengujian Campuran Aspal dengan Alat Marshall. Jakarta: Badan Standarisasi Nasional, 1991.

Sukirman, Silvia. (1999). Perkerasan Lentur Jalan Raya: Bandung: Nova.

Sukirman, Silvia. (2003). Beton Aspal Campuran Panas:Jakarta: Yayasan Obor Indonesia

Sukirman, Silvia. (2007). Beton Aspal Campuran Panas: Jakarta: Yayasan Obor Indonesia 